\title{
The Book of Hosea and the Last Days of the Northern Kingdom : The Methodological Problem
}

\author{
Nissinen, Martti Heikki \\ de Gruyter \\ 2018
}

Nissinen, M H 2018, The Book of Hosea and the Last Days of the Northern Kingdom : The Methodological Problem . in S Hasegawa, C Levin \& K Radner (eds), The Last Days of the Kingdom of Israel . Beihefte zur Zeitschrift für die alttestamentliche Wissenschaft, no. 511 , de Gruyter , Berlin , pp. 369-382 . https://doi.org/10.1515/9783110566604-018

http://hdl.handle.net/10138/310615

https://doi.org/10.1515/9783110566604-018

unspecified

acceptedVersion

Downloaded from Helda, University of Helsinki institutional repository.

This is an electronic reprint of the original article.

This reprint may differ from the original in pagination and typographic detail.

Please cite the original version. 


\title{
The Book of Hosea and the Last Days of the Northern Kingdom The Methodological Problem
}

\author{
Martti Nissinen (University of Helsinki)
}

\section{How Can We Reach the Eighth Century BCE?}

The essays published in this volume demonstrate that the historical reconstruction of the last decades of the Kingdom of Israel is a meaningful enterprise. Some significant problems notwithstanding, it is possible to base such a reconstruction on a number of biblical and Assyrian texts. Whatever took place within the Northern Kingdom during the very last years of its existence is a tricky question, however, because there are hardly any sources where such knowledge could be drawn from. Nadav Na'aman has recently argued that "Hosea is the only available source for discussing the kingdom's internal affairs in the second half of the eighth century BCE; hence the great importance of elucidating the potential contribution of Hosea for the historical investigation." This statement, of course, implies a great deal of confidence in the possibility that significant parts of the Book of Hosea actually date to the late eighth century BCE which, evidently, is no longer a matter of course.

The question of the dating of, not only the Book of Hosea, but also of the prophetic books in general has become a serious and manifold methodological problem. ${ }^{2}$ How

\footnotetext{
${ }^{1}$ Nadav Na'aman, "The Book of Hosea as a Source for the Last Days of the Kingdom of Israel," BZ 59 (2015): 232-56, esp. 234.

${ }^{2}$ For recent discussion, see, e.g., Reinhard G. Kratz, The Prophets of Israel (Winona Lake IN: Eisenbrauns, 2015); id., "Probleme der Prophetenforschung," in id., Prophetenstudien: Kleine Schriften II (Tübingen: Mohr Siebeck, 2011), 3-17; Brad E. Kelle, "The Phenomenon of Israelite Prophecy in Contemporary Scholarship," CurBR 12 (2014): 275-320; Jörg Jeremias, "Das Rätsel der Schriftprophetie," ZAW 125 (2013): 93-117; David M. Carr, The Formation of the Hebrew Bible: A New Reconstruction (New York: Oxford University Press, 2011), 317-38; Erhard Blum, "Israels Prophetie im altorientalischen Kontext: Anmerkungen zu neueren religionsgeschichtlichen Thesen," in "From Ebla to Stellenbosch": Syro-Palestinian Religions and the Hebrew Bible, ed. Izak Cornelius and Louis C. Jonker (Wiesbaden: Harrassowitz, 2008): 81-115; Hans M. Barstad, "What Prophets Do: Reflections on Past Reality in the Book of Jeremiah," in Prophecy in the Book of Jeremiah, ed. Hans M. Barstad and Reinhard G. Kratz (Berlin: de Gruyter, 2009): 10-32; Uwe Becker, "Die
} 
can the eighth century datings, or any datings predating the oldest manuscript evidence, be methodologically justified? Can the eighth century be assumed as the date of any part of the Book of Hosea unless the opposite is proven? Can textual growth caused by centuries of transmission be identified in the text available to us so that different dates could be given to the textual layers thus recognized? Or should one, rather, date the book as a whole - and if so, to which period of time? How can the material in the Book of Hosea be compared to other sources, biblical as well as non-biblical, in a historically responsible way? The view of the Book of Hosea as a historical document depends essentially on the answers given to these methodological questions, which I attempt to address in this chapter. ${ }^{3}$

First of all, in my view, datings of the Book of Hosea or any prophetic book should not be based on default positions preferring the alleged lifetime of the prophet after whom the book is named. Every dating must be argued for, we cannot date texts for the sake of convenience. Any principle of the type "innocent until proven guilty" should not be applied to texts that are neither accused of anything nor in need of being defended. Therefore, the practice of dating Hoseanic passages routinely to the eighth century without an argument to justify it is unacceptable. This practice may emerge from the often unspoken preference of the prophet for the later editors, early datings for late datings, or textual unity for disunity. ${ }^{4}$ Preferences like this are, however,

Wiederentdeckung des Prophetenbuches: Tendenzen und Aufgaben der gegenwärtigen Prophetenforschung," BTZ 21 (2004): 30-60.

${ }^{3}$ Cf. my previous musings in, e.g., Martti Nissinen, Ancient Prophecy: Near Eastern, Biblical, and Greek Perspectives (Oxford: Oxford University Press, 2017), 144-67; id., "Comparing Prophetic Sources: Principles and a Test Case," in Prophecy and the Prophets in Ancient Israel, ed. John Day (London: T\&T Clark, 2010): 3-24; id., "The Historical Dilemma of Biblical Prophetic Studies," in Prophecy in the Book of Jeremiah, ed. Hans M. Barstad and Reinhard G. Kratz (Berlin: de Gruyter, 2009): 103-20.

${ }^{4}$ For a good representation of this view, see Francis I. Andersen and David Noel Freedman, Hosea: A New Translation with Introduction and Commentary (Garden City NY: Doubleday, 1980), 59: "In both cases [scil. the unity of the Book of Hosea and the integrity of the text] our premise and point of departure are conservative, that the book is essentially the work of a single person, and that the text is basically sound. These are hardly ringing affirmations; they are more like defensive desperation. If the opposite were true, if many hands and voices could be found from the book, then we would have the thankless and ultimately fruitless task of apportioning the work among a variety of people whose 
difficult to reconcile with the documented evidence of textual transmission. Drawing historical conclusions from the Book of Hosea (or any other book) on the basis of such default positions is likely to introduce errors into the historical record.

How could such errors, then, be avoided? At the very least we must be aware of the nature of our source material. The oldest "hard" evidence of the existence of the Book of Hosea (like any other book of the Hebrew Bible) comes from the Dead Sea Scrolls. Parts of the Book of Hosea have been preserved in three scrolls, that is, 4QXII , $4 \mathrm{QXII}^{\mathrm{d}}$ and $4 \mathrm{QXII}{ }^{\mathrm{g}}$, all dating to the first half of the first century BCE. ${ }^{5}$ This material alone, together with the Old Greek translation of the Book of Hosea which in some cases is arguably translated from a Hebrew text different from the Masoretic text, ${ }^{6}$ demonstrates that textual transmission not only preserved ancient texts but also changed them. ${ }^{7}$ We may assume that the texts transmitted in the Scrolls often date back several centuries, but the documented evidence of textual growth makes it impossible to believe that any of the available manuscripts provides us with a text that had remained unchanged for such a long time. ${ }^{8}$ In the case of Hosea, the documented changes are usually less than dramatic, but they testify to actual scribal interventions

existence is hypothetical, and whose only distinguishing mark is some obscurity or inconsistency in the text."

${ }^{5}$ See Brian Webster, "Chronological Index of the Texts from the Judaean Desert," in The Texts from the Judaean Desert: Indices and an Introduction to the Discoveries in the Judaean Desert Series, ed. Emanuel Tov (Oxford: Clarendon Press, 2002): 393, 397. Taken together, these fragments include the following verses at least partially: $1: 6-9 ; 2: 1-5,13-19,22-25 ; 3: 1-5 ; 4: 1-19 ; 5: 1 ; 6: 3,8-11 ; 7: 1,12-$ 16 ; $8: 1 ; 9: 1-4,9-17 ; 10: 1-14 ; 11: 2-5,6-11 ; 12: 1-15 ; 13: 1,3-13,15 ; 14: 1,3-6,9-10$; see the convenient translation of the Dead Sea Scrolls material in Martin Abegg, Peter Flint and Eugene Ulrich, The Dead Sea Scrolls Bible (New York: Harper, 1999), 420-27.

${ }^{6}$ For instance, the Greek text of Hos 13:4 must have been translated from a Vorlage much longer than the MT but similar to $4 \mathrm{QXII}$.

${ }^{7}$ For $4 \mathrm{QXII}$, see Hanne von Weissenberg, "Changing Scripture? Scribal Corrections in MS 4QXII"," in Changes in Scripture: Rewriting and Interpreting Authoritative Traditions in the Second Temple Period, ed. Hanne von Weissenberg, Juha Pakkala and Marko Marttila (Berlin: de Gruyter, 2011): $247-71$.

${ }^{8}$ For examples of documented evidence of textual growth, see Reinhard Müller, Juha Pakkala and Bas ter Haar Romeny, Evidence of Editing: Growth and Change of Texts in the Hebrew Bible (Atlanta GA: SBL Press, 2014). 
to the text that cannot be dismissed either. ${ }^{9}$ This is why any dating beyond the age of the extant manuscript material requires a diachronic theory concerning the transmission of the given text through a long period of time. Creating such a theory, however, immediately raises further methodological questions. While extant textual evidence shows that the idea of textual growth is not based on imagination, detecting the early phases of textual transmission on the basis of the text itself without empirical evidence is a matter of ongoing debate.

Diachronic analysis is, of course, the most traditional way of approaching the Book of Hosea in academic biblical studies, and has been practiced by many scholars over the last decades, myself included. Traditionally, the diachronic enterprise has been motivated by the search of the original message of the prophet by way of separating later additions from the original text and identifying the oldest material, which is often virtually equated with the words once uttered by the prophet Hosea. The ripest fruit carried by this branch of methodology can be found in the work of Jörg Jeremias, according to whom the essential contents of the Book of Hosea date back to the last years of the Northern Kingdom and the time immediately following the catastrophe: "Das Buch Hosea hat seine entscheidende Prägung im untergegangenen Nordreich erhalten." 10 According to Jeremias, the earliest form of the book is essentially the work of his disciples, who had collected and interpreted the prophet's words, whereas the book as we know it was edited and augmented in Judah after the collapse of the Northern Kingdom. A similar line of thought has been followed by many scholars. ${ }^{11}$

\footnotetext{
${ }^{9}$ Cf. von Weissenberg, "Changing Scripture," 269: "Even the smaller, individual scribal additions and corrections in manuscripts illustrate the minor forms of growth in the texts. They attest to the scribal contribution to the development of the texts that became the Hebrew Bible."

${ }^{10}$ Jeremias, "Das Rätsel der Schriftprophetie," 113; cf. many well-known works of Jörg Jeremias, e.g., Studien zur Theologie des Alten Testaments (Tübingen: Mohr Siebeck, 2015, ed. Friedhelm Hartenstein and Jutta Krispenz,), 269-87 (= "Die Anfänge der Schriftprophetie," 1996) and 311-25 (= "Prophetenwort und Prophetenbuch: Zur Rekonstruktion mündlicher Verkündung der Propheten," 1990); Hosea und Amos: Studien zu den Anfängen des Dodekapropheton (Tübingen: Mohr Siebeck, 1996); Der Prophet Hosea (Göttingen: Vandenhoeck \& Ruprecht, 1983).

${ }^{11}$ E.g., Na'aman, "The Book of Hosea as a Source," 255-56 dates Hosea's prophecies to the time of Hoshea, the last king of Israel, and the earliest scroll to the time immediately after the Assyrian annexation of the kingdom (720 BCE).
} 
Another type of diachronic analysis of the Book of Hosea is not concerned with finding the prophet's message or even the original core of the book but reckon with a complicated process of redaction and/or Fortschreibung over a long period of time. ${ }^{12}$ These studies have typically identified only scattered remains of material datable to the eighth century BCE, shifting the emphasis from the prophet and his disciples to the scribal circles of the monarchic and postmonarchic periods.

Diachronic studies reconstructing the emergence of the Book of Hosea have done their best to remove the illusionary innocence with regard to the textual transmission and its relation to historical events. Since, however, no two scholars arrive at the same conclusion but the results typically vary from study to study, many colleagues have found it difficult to decide on whose analysis is the more reliable one. Therefore, the possibility of unfolding the process of textual growth with a precision that could reveal even relative datings of each individual passage in the book has been seriously questioned. The ever-changing results of diachronic analyses have been found frustrating enough for many scholars to abandon them altogether and to read the texts synchronically, giving up the attempt to reconstruct the hypothetical phases of textual transmission.

Textual growth in prophetic books is not usually denied altogether, although acknowledging its existence often does not go beyond lip-service. Some scholars say they are reading the "final form" of the text; however, there is no such thing as the final form of any biblical book, unless modern editions of the Masoretic text are regarded as such. ${ }^{13}$ Of course, any given form of the text can form the basis of an

${ }^{12}$ E.g., Roman Vielhauer, Das Werden des Buches Hosea: eine redaktionsgeschichtliche Untersuchung (Berlin: de Gruyter, 2007); Susanne Rudnig-Zelt, Hoseastudien: Redaktionskritische Untersuchungen zur Genese des Hoseabuches (Göttingen: Vandenhoeck \& Ruprecht, 2006); Henrik Pfeiffer, Das Heiligtum von Bethel im Spiegel des Hoseabuches (Göttingen: Vandenhoeck \& Ruprecht, 1999); Martti Nissinen, Prophetie, Redaktion und Fortschreibung im Hoseabuch: Studien zum Werdegang eines Prophetenbuches im Lichte von Hos 4 und 11 (Kevelaer: Butzon \& Bercker and NeukirchenVluyn: Neukirchener Verlag, 1991); Gale A. Yee, Composition and Redaction in the Book of Hosea: $a$ Redaction Critical Investigation (Atlanta GA: Scholars Press, 1987); cf. Reinhard G. Kratz, "Die Redaktion der Prophetenbücher," in id., Prophetenstudien, 32-48.

${ }^{13}$ Cf., e.g., Eugene Ulrich, "Our Sharper Focus on the Bible and Theology Thanks to the Dead Sea Scrolls," CBQ 66 (2004): 1-24; Anneli Aejmelaeus, "Licence to Kill? Deut 13:10 and the Prerequisites 
analysis that does not attempt to go historically beyond the textual witness itself. However, if we want to relate the Book of Hosea historically with the last days of the Northern Kingdom, the so-called "final form" readings clearly lead to an impasse.

A synchronic reading of the Book of Hosea does not as such require an eighth-century BCE setting, even though this very often seems to be assumed. A synchronic analysis can take the text as the product of postmonarchical readerships, relating the text of the Book of Hosea to a later historical period when one can suppose the text to have reached more or less the shape known to us from existing textual evidence. Thus, for instance, Ehud Ben Zvi consistently reads the book as the product of the literati of the late Persian period. ${ }^{14}$ This way of reading the text neither denies the possibility that some parts of the book indeed have earlier origins, nor enables sorting these parts out. Historical links can be made to the time chosen as the setting of the alleged (re)readership of the book, but historical connections with the events of the eighth century BCE fall entirely out of scope.

The methodological problem of relating the Book of Hosea to the last days of the Northern Kingdom, thus, consists of the following components:

(1) The oldest manuscript evidence from the Dead Sea Scrolls is enough to demonstrate that textual development and growth took place; however, coming from the first century BCE, it documents only the very latest phases of textual transmission and does not help to date individual passages of the book to older periods.

(2) There are good grounds to assume that the text of the Book of Hosea existed in some form several centuries earlier than the Dead Sea Scrolls. The book is one of the "Twelve Prophets" already in the oldest textual witnesses, but one can assume that the books included in this collection existed as individual scrolls before they were joined

of Textual Criticism," in Verbum et calamus: Semitic and Related Studies in Honour of the Sixtieth Birthday of Professor Tapani Harviainen, ed. Hannu Juusola, Juha Laulainen and Heikki Palva (Helsinki: Finnish Oriental Society, 2004): 1-22.

${ }^{14}$ Ehud Ben Zvi, Hosea (FOTL 21A/1; Grand Rapids MI: Eerdmans, 2005); cf. James M. Bos, Reconsidering the Date and Provenance of the Book of Hosea: The Case of Persia-Period Yehud (LHBOTS 580; London: Bloomsbury, 2013). 
together in several phases, and that each phase of transmission is likely to have transformed the text. ${ }^{15}$ However, the late date of the earliest textual witnesses makes it impossible simply to equate the extant textual evidence with any earlier form of the text. The Book of Hosea as we know it is already part of a larger composition and the product of a long chain of textual transmission, but no documented evidence is available to help with the reconstruction of this process. This is essentially due to the tendency of the texts themselves to hide rather than to reveal their editorial history. ${ }^{16}$

(3) If we want to establish a direct historical connection from the Book of Hosea to the last days of the Northern Kingdom, we should be able to date at least some parts of Hosea to this period of time. Diachronic studies detecting the oldest parts of the Book of Hosea have yielded exact results, but these have been varying enough to raise suspicions about the viability of even the diachronic methodology. The ever-changing results of ever-greater precision have been seen as pointing towards problems in the method itself. But the task cannot be fulfilled by way of synchronic reading either unless the book as a whole is dated to the $730 \mathrm{~s}-720$ s, which is not viable for reasons just mentioned.

So have we ended up in a cul-de-sac: if synchronic analysis is not the way to go and the results of diachronic studies are found to be disappointing, what else can we do other than give up entirely on the task of connecting the Book of Hosea with the last

\footnotetext{
${ }^{15}$ For theories concerning the history of redaction of the "Book of the Twelve," see, e.g., Jakob Wöhrle, Die frühen Sammlungen des Zwölfprophetenbuches: Entstehung und Komposition (Berlin: de Gruyter, 2006); Aaron Schart, Die Entstehung des Zwölfprophetenbuches: Neubearbeitungen von Amos im Rahmen schriftenübergreifender Redaktionsprozesse (Berlin: de Gruyter, 1998); James D. Nogalski, Literary Precursors to the Book of the Twelve (Berlin: de Gruyter, 1993); cf. Ben Zvi who finds it impossible to reconstruct redactional processes from the existing text. For two different views of the "Twelve Hypothesis", see Ehud Ben Zvi and James D. Nogalski, Two Sides of a Coin: Juxtaposing Views on Interpreting the Book of the Twelve/The Twelve Prophetic Books (with an introduction by Thomas Römer; Piscataway NJ: Gorgias Press, 2009).

${ }^{16}$ According to Ehud Ben Zvi, "the ongoing process of redaction was not bent on promoting, or archiving and analyzing itself; instead its function was to shape a series of texts in which the last, if successful, was meant to supersede and erase the memory of the previous one" ("Is the Twelve Hypothesis Likely from an Ancient Reader's Perspective?" in Ben Zvi and Nogalski, Two Sides of a Coin, 46-96, esp. 59).
} 
days of the Kingdom of Israel? Or is there a historically responsible way of doing this?

\section{Historical Echoes from the Eighth Century?}

Perhaps we could try circumventing the problems of diachronic methodology by way of looking for clues in the text that seem to point towards an eighth-century date, and, if possible, comparing such clues with the available historical data of the last days of the kingdom of Israel. If they seem to fit this documentary environment, they could be dated to the same period of time. The best candidates for an early date would be passages that do not show clear signs of intertextual influence, and are not to be taken as Fortschreibung of earlier texts but rather as belonging to the source materials of an early collection upon which the Book of Hosea has grown.

As many contributions to this volume demonstrate, the fall of Samaria and the subsequent de- and repopulations of the area can indeed be confirmed by Assyrian sources and even by archaeological evidence. ${ }^{17}$ The problem is rather how to reconstruct the internal affairs of the kingdom of Israel, of which there is no documentation outside of, or even within, the Hebrew Bible. The following three examples may illustrate the case.

(1) A contemporary reflection of a disturbing political event could perhaps be found in Hos 7:3-7, a highly enigmatic passage that seems to reflect on the murder of a king, perhaps one of the successors of Jeroboam II. Of the last kings of Israel only

\footnotetext{
${ }^{17}$ For archaeological evidence of the devastation, see Zvi Gal, Lower Galilee during the Iron Age (Winona Lake IN: Eisenbrauns, 1992), 108-109. Cf. Avraham Faust, "Settlement, Economy, and Demography under Assyrian Rule in the West: The Territories of the Former Kingdom of Israel as a Test Case," JAOS 135 (2015): 765-89, who concludes that the Assyrians "did not really care about the fate of the areas they conquered. They carried off whatever they could and their investment was minimal" (782). However, the Assyrians did not just plunder but also, for example, looked after the water supply in Samaria as reported in a letter from the time of Sargon II: Simo Parpola, The Correspondence of Sargon II, Part I: Letters from Assyria and the West (Helsinki: Helsinki University Press, 1987), no. 255. According to Angelika Berlejung, "The Assyrians in the West: Assyrianization, Colonialism, Indifference, or Developmental Policy?" in Congress Volume Helsinki 2010, ed. Martti Nissinen (Leiden: Brill 2012): 21-60, esp. 48), "[s]uccess was maximal profit with minimal investment."
} 
Menahem is said to have died peacefully, whereas his predecessors Zechariah and Shallum as well as his followers Pekahiah and Pekah were killed. A rather laconic report of the four coups d'état that took place after Jeroboam II can be found in $2 \mathrm{Kgs}$ 15:8-31, a passage probably based on court chronicles that were used as sources of the Deuteronomistic History. ${ }^{18}$ Hos 7:3-7 seems to give a metaphoric account of the day when one of the kings was murdered. The actors "make glad" (7:3) the unsuspecting king and his officials, who get drunk, presumably in the privacy of the royal palace. They become easy prey for the murderers who, compared with a heated oven, just wait "from the kneading of the dough until it is leavened," that is, for the opportunity to "devour their rulers" (7:7). Compared to the account of $2 \mathrm{Kgs}$, such an event could best be identified with the murder of Pekahiah, committed by his captain (šălî̌s) Pekah, who conspired against him with fifty Gileadites and attacked him in the citadel of the palace ( $2 \mathrm{Kgs} 15: 25) .{ }^{19}$ This is what I argued in my master's thesis in 1984, and I would still like to agree with myself. The passage is probably neither interpreting a pre-existing text in the Book of Hosea nor is it dependent on another biblical text outside the book, hence it could belong to the material from which the early version of the book is composed. ${ }^{20}$ However, I have to admit that the link between Hos 7:3-7 and Pekahiah's murder derives from what is visible through the keyhole provided by $2 \mathrm{Kgs} 15: 25$. The two sources seem to connect nicely, but the connection depends entirely on what we happen to see.

(2) Further echoes from the last days of the Northern Kingdom, either contemporary or slightly later, can be heard in passages of the Book of Hosea that reflect the Fall of Samaria. The demise of the Northern Kingdom, or Ephraim (the name may refer to

\footnotetext{
${ }^{18}$ For court chronicles as the sources of the Deuteronomistic history, see Lester L. Grabbe, $1 \& 2$ Kings: An Introduction and Study Guide: History and Story in Ancient Israel (London: Bloomsbury, 2017), 21-28; cf., e.g., Ernst Würthwein, Die Bücher der Könige: 1. Kön. 17-2. Kön. 25 (Göttingen: Vandenhoeck \& Ruprecht, 1984), 376-84.

${ }^{19}$ Pekahiah has not been among the prime suspects in this murder case; see, however, Andrew Alexander Macintosh, A Critical and Exegetical Commentary on Hosea (Edinburgh: T\&T Clark, 1997), 256.

${ }^{20}$ Cf. Vielhauer, Das Werden des Buches Hosea, 86-92, according to whom verses 7:5-6 go back to oral words of northern origin and the remaining verses to the oldest written layer (erste Verschriftung). Rudnig-Zelt, Hoseastudien, 212-30, sees a pre-exilic core in the passage (verses 7:4b, 5b), however, without a reference to the murder of a king.
} 
the truncated kingdom in the time of the last king Hoshea ${ }^{21}$ ), is reflected in several passages that sound like fragments of laments $(9: 10-17 ; 11: 1-5)$. Some passages in the Book of Hosea could be imagined to go back to contemporary laments; for instance, Hos 10:5-8 could be based on something like the following: ${ }^{22}$

\begin{tabular}{|c|c|}
\hline$l[' g l w t b y t ' w n]$ & For [the calf of Beth-awen ${ }^{23}$ ] \\
\hline ygwrw škn šmrwn & the inhabitants of Samaria tremble. \\
\hline$k y$ 'bl 'lyw' $m w$ & Its people mourn for it, \\
\hline wkmryw 'lyw ygylw & its priests wail over it \\
\hline ['l kbwdw ky glh mmnw] & [over its glory that has departed from $\mathrm{it}^{24}$ ]. \\
\hline$g m$ 'wtw l'šwr ywbl & The thing itself is carried to Assyria \\
\hline mnḥh lmlky rb & as tribute to the Great $\mathrm{King}^{25}$. \\
\hline b̌̌nh 'prym yqh & Ephraim has received shame, \\
\hline wybwš yśr ${ }^{\prime} l m$ 'ṣtw & and Israel is ashamed for his own counsel. \\
\hline ndmh šmrwn mlkh & Samaria and its king perish \\
\hline kqsp'l pny mym & like a splinter on the face of the waters. \\
\hline
\end{tabular}

[wnšmdw bmwt 'wn hṭt'tyśr'l [The high places of Awen, the sin of Israel, shall qwṣ wdrdry'lh ' $l \mathrm{mzbhwtm}$ ] be destroyed. Thorn and thistle shall grow up on their altars. $]^{26}$

\footnotetext{
${ }^{21}$ Thus Na'aman, "The Book of Hosea as a Source," 238-39.

${ }^{22}$ This reconstruction is based on my analysis in Nissinen, Prophetie, Redaktion und Fortschreibung, 309-12; cf. the different reconstructions of Pfeiffer, Das Heiligtum von Bethel, 103-17; Vielhauer, Das Werden des Hoseabuches, 165-72; Melanie Köhlmoos, Bet-El - Erinnerungen an eine Stadt: Perspektiven der alttestamentlichen Bet-El-Überlieferung (Tübingen: Mohr Siebeck, 2007), 126-31.

${ }^{23}$ The peculiar and pejorative expression 'eglôt Bêt-āwen (pl. fem.) is probably inspired by the Deuteronomistic polemics against the calf of Bethel, replacing the original name of the object to which the sg. masc. suffixes in the following bicolon refer.

${ }^{24}$ This sentence probably serves as a secondary explanation of the masculine suffix in 'ālâw "for it/over it," which is not applicable to eglôt.

${ }^{25}$ Adopting the usual reading malkî rāb instead of melek yāreb (MT).
} 
w'mrw lhrym kswnw

wlgb'wt nplw' lynw
They shall say to the mountains: "Cover us!" and to the hills: "Fall on us!"

This passage may originally refer to the transportation of a precious item, presumably, a divine statue, to Assyria. ${ }^{27}$ It resonates well with the Nimrud Prism of Sargon II, which reads: "[The inhabitants of Sa]maria who agreed [and plotted] with a king [hostile to] me, not to endure servitude and not to bring tribute to Assur and who did battle, I fought against them with the power of great gods, my lords. I counted as spoil 27,280 people together with their chariots and gods in which they trusted" (lines iv 25-32). ${ }^{28}$ One could easily imagine laments like the one possibly quoted in Hos 10:5$8^{*}$ to have been uttered after the fall of Samaria, if not by prophets, then perhaps by professional lamenters similarly to the ones known from Assyrian records. ${ }^{29}$

Prophecy and lament are related performances both in the Hebrew Bible and in the ancient Near Eastern sources, ${ }^{30}$ and the literary reflection of the fate of the city of Samaria and the Kingdom of Israel may have been inspired by source texts representing both genres. The Mesopotamian kalû's were not only singers but also

\footnotetext{
${ }^{26}$ Verse 8a reads like a later, prosaic theological interpretation of the original lament.

${ }^{27}$ Cf. Köhlmoos, Bet-El, 135-38.

${ }^{28}$ See C. J. Gadd, “Inscribed Prisms of Sargon II from Nimrud,” Iraq 16 (1954): 173-201, esp. 179
} 80. For other texts of Sargon II related to the conquest of Samaria, see the chapter of Frahm in this volume

${ }^{29}$ However, the assumed reference to Samarian lamenters in a text from Calah - read as 3 ŠÚ.MEŠ KUR.Sa-mir-na-a-a by Stephanie Dalley and J. N. Postgate, The Tablets from Fort Shalmaneser (London: British School of Archaeology in Iraq, 1984), no. 121: 6 and, assuming that ŠÚ was used as a logogram for kalû, interpreted as a reference to "three Samarian lamentation-priests" by Kyle Lawson Younger Jr., "The Deportations of the Israelites," JBL 117 (1998): 221 - cannot be used as evidence for the existence of Samarian lamenters, as the passage needs to be read 3-šú.MEŠ KUR.Sa-mir-na-a$a$, meaning "Third Men (of a chariot crew) from Samaria" (pers. comm., Karen Radner); cf. also Radner's chapter in this volume.

${ }^{30}$ Cf. Martti Nissinen, "Biblical Prophecy from a Near Eastern Perspective: The Cases of Divine Kingship and Divine Possession," in Congress Volume Ljubljana 2007, ed. André Lemaire (Leiden: Brill, 2010): 441-68, esp. 458-61. 
scribes who wrote divinatory texts. ${ }^{31}$ If this was true also in Samaria (which can only be speculated), this could explain the early textualization of such laments. Laments like Hos $10: 5-8^{*}$ could have belonged to the material comprising the first beginnings of what we know as the Book of Hosea. ${ }^{32}$ The later redactors have subsequently used this material as a tool of criticism against past and/or contemporary religious practices referred to with the pejorative designation designation 'âwen (“iniquity").

(3) My third example is the possible reference to the so-called Syro-Ephraimite war in 734-732 BCE. This war can be reconstructed from biblical texts only (2Kgs 16:5; 2Chr 28:5-8; Isa 7:1-9), but, if it actually took place, as scholars usually assume, it may be interpreted as an act of hostility towards Ahaz, the king of Judah, who refused to join the anti-Assyrian alliance. ${ }^{33}$ A contemporary echo of it is usually heard in Hos $5: 8-14 * .{ }^{34}$ The alarm blown in three cities from south to north, Gibeah, Ramah, and Beth-Awen (scil. Bethel) (5:8), as well as the accusation of the princes of Judah acting "like those who remove the landmark" (5:10) give the impression of a Judahite attack to the area of the Kingdom of Israel and refers to Ephraim's resorting to the help of Assyria (5:13). Nothing of this is known from other sources which rather present the Northern Kingdom as attacking Judah, and this is exactly the reason why

\footnotetext{
${ }^{31}$ See, e.g., Francesca Rochberg, In the Path of the Moon: Babylonian Celestial Divination and Its Legacy (Studies in Ancient Magic and Divination 6; Leiden: Brill, 2010), 247.

${ }^{32}$ I am, thus, suggesting an earlier date to this passage than Vielhauer, Das Werden des Buches Hosea, 176-77, 227-78, according to whom already the basic layer of Hos 10:1-8 is Deuteronomistic. This is probably true for the Kultpolemik in chapter 10 in general, but not necessarily for the source material used by the editors.

${ }^{33}$ See, e.g., Nadav Na'aman, "Let Other Kingdoms Struggle with the Great Powers — You, Judah, Pay the Tribute and Hope for the Best: The Foreign Policy of the Kings of Judah in the Ninth-Eighth Centuries BCE," in Isaiah's Vision of Peace in Biblical and Modern International Relations: Swords into Plowshares, ed. Raymond Cohen and Raymond Westbrook (New York: Palgrave MacMillan, 2008): 55-73, esp. 62-64.

${ }^{34}$ Thus the majority of scholars following Albrecht Alt, "Hosea 5,8-6,6: ein Krieg und seine Folgen in prophetischer Beleuchtung," NKZ 30 (1919): 537-68, repr. in id., Kleine Schriften zur Geschichte des Volkes Israel, vol. 2 (Munich: Beck, 1953): 163-87. Even Vielhauer, Das Werden des Buches Hosea, 225-26 finds remnants of oral proclamation from the last days of the Northern Kingdom in verses 5:8$11^{*}$, whereas the written text in verses $5: 8-14$ belongs to the late 8 th century layer (erste Ergänzungsschicht) written from the perspective of Judah. Rudnig-Zelt, Hoseastudien, 157-77, reconstructs a complicated editorial process, dating the polemics against Samaria to its latest phases.
} 
it could be interpreted as a reference to historical events rather than as interpretation or Fortschreibung of an already existing text. Hence, the text could be interpreted as referring to events of the Syro-Ephraimite war unknown from other sources, such as the attack of Judah on Israel and Israel's turning to Assyria for help. The passage is now embedded and reworked in the context of the Book of Hosea, but the old oracle could originate from either Israel or Judah.

Of course, the passage can be interpreted otherwise. Na'aman, for example, dates the counter-attack of Judah to the time of Hoshea, the last king of Israel, when Israel was at its weakest. ${ }^{35}$ Ben Zvi, on the other hand, does not see a compelling reason to connect the passage with the historical circumstances of the last days of the kingdom of Israel: "The text as it stands does not lead to such a reading" which is also unknown to ancient readerships who knew about the Syro-Ephraimite war on the basis of biblical texts. ${ }^{36}$

Ben Zvi is right in stressing that the reconstructions of the historical scenery behind passages in the Book of Hosea are based on the assumption that the texts directly reflect the historical prophet's oral speeches and should, therefore, be given a historical setting within his lifetime. "Given that there are only a limited number of political events during that period that are known and potentially relevant, the only question is which one would fit better a particular speech." 37 This easily leads to a chain of circular arguments causing erroneous historical conclusions. On the other hand, if one follows the principal that when writing history, all potential sources should be considered and nothing should be ruled out a priori, even secondary sources such as prophetic books deserve to be critically scrutinized. ${ }^{38}$ Therefore, the possibility that a given passage in the Book of Hosea actually provides a keyhole view into the historical landscape, however narrow, should not be dismissed at the outset, even though the secondary nature of the evidence should never be forgotten. Individual passages of the Book of Hosea may contain reminiscences of real historical

\footnotetext{
${ }^{35} \mathrm{Na}$ 'aman, "The Book of Hosea as a Source," 239-40.

${ }^{36}$ Ben Zvi, Hosea, 140.

${ }^{37}$ Ben Zvi, Hosea, 141.

${ }^{38}$ See Lester L. Grabbe, Ancient Israel: What Do We Know and How Do We Know It? (London: T\&T Clark 2007), 35-36.
} 
events, but they always appear re-contextualized in literary settings created by scribes who may or may not have been aware of the actual historical reference.

Many other texts in the Book of Hosea, most recently collected by Na'aman, ${ }^{39}$ could be highlighted to demonstrate the original connection of the text with the fall of Samaria and the last days of the Kingdom of Israel. The problem with using such clues as evidence of events that took place in the 730s-720s BCE is that, however nicely they seem to fit our picture of that period of time, there is always the risk of potest, ergo and circular reasoning. For example, the recurrent juxtapositioning of Egypt and Assyria (Hos 7:11; 9:3; 11:5, 11; 12:1) undoubtedly makes sense with regard to the political maneuvres of Hoshea, the last king of Israel-provided that they actually took place and $2 \mathrm{Kgs} 17: 3 \mathrm{~b}-5 \mathrm{a}$ is not later historical speculation as suggested by Christoph Levin elsewhere in this volume. The problem is, evidently, that the parallelism of Egypt and Assyria could be used by any subsequent writer reflecting the event. For later readers, the names can stand for Ptolemaic Egypt and Seleucid Syria. ${ }^{40}$ Even Samaria was still there, providing itself continually as a target for theological criticism for circles who considered that the wrong kind of Yahwism was practiced in the north. ${ }^{41}$ Therefore-and this is generally the problem with the dating of individual passages in Hosea-even if an eighth-century setting makes sense, it cannot automatically be preferred.

\section{Evidence or Reflection of Eighth-Century Events?}

I am convinced that the beginnings of the Book of Hosea must be sought from the last days of the Northern Kingdom or shortly thereafter. It is virtually impossible to imagine the emergence of the Book of Hosea without the contemporary experiences

\footnotetext{
${ }^{39}$ Na'aman, "The Book of Hosea as a Source," passim.

${ }^{40}$ Cf. Christoph Levin, The Old Testament: A Brief Introduction (Princeton NJ: Princeton University Press, 2005), 133 with regard to Hos 7:8-11.

${ }^{41}$ As Gary N. Knoppers, Jews and Samaritans: The Origins and History of Their Early Relations (Oxford: Oxford University Press, 2013) emphasizes, there was no absolute breakdown of relations between Yehud and Samaria in the first centuries BCE but, rather, a considerable cultural and religious overlap. The debate on the common heritage and religious identity is evidence of the overlap and continuity, not of the breakdown.
} 
of the end of the Northern Kingdom. The fall of Samaria must be considered the decisive event that triggered the emergence of the book, in whatever way this happened over the subsequent centuries. It is usually assumed that the redaction and transmission of the book took place in Judah, not only because of the multiple mentions of Judah, which are often ascribed to a specific redaction, but also because of the harsh criticism of Israel/Ephraim and Samaria throughout the book. ${ }^{42}$ However, this criticism does not need to derive from the eighth century only, since, as Christoph Levin has argued, there was enough reason for it even later when the Samari(t)an society and worship gradually became an issue to the (religious) elite of Jerusalem. ${ }^{43}$ The echoes on the last days of the Northern Kingdom in what may have constituted the earliest form of the Book of Hosea were readily available for interpretations of the subsequent generations who likewise reflected their relationship with what took place in the Northern Kingdom.

It is, thus, problematic to quote verses of the Book of Hosea as quasi-eyewitness reports of events that took place in the 730s-720s BCE, even if we have good grounds to assume that some material in the book indeed dates back to this historical period. Some passages in Hosea, like the ones discussed above, undeniably give the impression of contemporary experience, indeed making sense when compared to what we know about the last days of the Kingdom of Israel from other sources. However, even these passages rarely reveal historical data that could not even theoretically go back to later reflection. Potest, we can say quite often, but we should be careful with the ergo.

Without suggesting anything that has not been said and done before, I would like to argue that if any part of the Book of Hosea actually derives from a time not too distant from the last days of the kingdom of Israel (and I do believe this to be the case to some extent), such passages can only be identified by way of the diachronic method and comparative analysis. Individual parts of the Book of Hosea should not be dated randomly but the dating of each passage should be based on a well-argued theory

\footnotetext{
${ }^{42}$ See, e.g., Jeremias, Der Prophet Hosea, 18-19 and passim.

${ }^{43}$ Levin, The Old Testament, 129-33; cf. the late "Samariapolemik" reconstructed by Rudnig-Zelt, Hoseastudien, 271-73.
} 
concerning the emergence, growth, and transmission of the text of the Book of Hosea. The methodological problem is how to sort datable passages out from a text that is the product of a process of long textual transmission, and if there is a great deal of uncertainty about this, one should be cautious about making precise contemporary connections between the last days of the Kingdom of Israel and the literary work we call the Book of Hosea. This is why it is so difficult to detect independent historical information in the Book of Hosea that could be reliably used as evidence of the last days of the Northern Kingdom. Even texts that seem to connect well with historical circumstances known from other sources may go back to subsequent reflection and Fortschreibung.

However, the book can be used as a powerful document of the reflection and interpretation of this historical event. The event itself is real. The fall of the Northern Kingdom and its capital Samaria is something that can be historically reconstructed from the available sources. It would be nonsensical to deny the connection of the Book of Hosea with this event, but the nature of the connection is evidently more complicated than a simple contemporary eyewitness response. The book and the historical event are rather linked through social memory, which creates an indirect connection between the text and the shared past - not only through remembering but also by way of forgetting. ${ }^{4}$

\footnotetext{
${ }^{44}$ Cf. Ehud Ben Zvi, "Remembering the Prophets through the Reading and Rereading of a Collection of Prophetic Books in Yehud: Methodological Considerations and Explorations," in Remembering and Forgetting in Early Second Temple Judah, ed. Ehud Ben Zvi and Christoph Levin (Tübingen: Mohr Siebeck, 2012): 17-44. For social memory and the collective past, see also Geoffrey Cubitt, History and Memory (Manchester: Manchester University Press, 2007), 199-249.
} 